\title{
Learning and growing in a foreign context: Review of literature on cross-cultural adaptation of international students
}

\author{
Daniela Hrehová ${ }^{1, *}$ and Pavel Žiaran ${ }^{2}$ and Andrea Seňová ${ }^{3}$ \\ ${ }^{1}$ Technical University in Košice, Department of Social Sciences, Vysokoškolská 4, 04042 Košice, \\ Slovakia \\ ${ }^{2}$ Faculty of Management of the University of Prešov, Konštantínova 16, 08001 Prešov, Slovakia \\ ${ }^{3}$ Technical University in Košice, Department of Social Sciences, Vysokoškolská 4, 04042 Košice, \\ Slovakia
}

\begin{abstract}
Research background: Research background: The evolving opportunities of studies at foreign universities and the geographical expansion of the labour market create the need of facilitating a process of adapting students to studying and working. Despite a rapid increase in the number of international students in the higher education sector, little is known about their adaptation.

Purpose of the article: The aim is to point out the topicality and importance of the issue of adaptation of foreign students in the globalizing world in the form of the bibliometric analysis of scientific publications.

Methods: We use a combination of methods: setting parameter search by keywords, number of citations and publications, their segmentation, as defined by classification disciplines, and graphical analysis. The sample used consists of articles from WoS - Core Collection.

Findings \& Value added: The findings of this study have important implications for universities and educators in relation to helping students in their pursuit of academic and work success. The results provide a broader view of the research continuum and the publishing trends, in the domain of the adaptation process of students studying at foreign universities.
\end{abstract}

Keywords: bibliometric analysis; students; adaptation; study; labour market

JEL Classification: $112 ; J 24$

*Corresponding author: daniela.hrehova@tuke.sk 


\section{Introduction}

Foreign migration is closely connected with the globalisation process, and it is one of its natural consequences. The world has been internationalised and globalised, the transnational mobility of students all over the world included. The ever-developing possibilities of studying abroad and the geographic expansion of the labour market have resulted in an increased mobility of young people (Johnson, 2020). Foreign students also represent a significant part of the Slovak higher education sector. Universities are responsible for the education of foreign students and the development of meta competences in a country and their overall adoption (adaptation, study, personal relations, work activities, everyday life etc.). Thus, study provides all the opportunities for their success, namely: academic, personal and professional. The paper has emphasized the up-to-datedness of the issue of foreign students' adaptation to changes in living conditions, and in the study and work environment. It presents the starting points leading towards the understanding of concurrently running adaptations in the form of the bibliometric analysis of scientific publications. The topic of the article has resulted from a project dealt with at the Department of Social Sciences, Technical University of Košice under the name Education of Foreign Students with the emphasis on creating key competences in the context of building a job career and inclusion in the Slovak labour market, which has focused on such education of students that would increase their success in adaptation to higher education study, their competence and their asserting in the labour market (Ferencz et al., 2020).

\section{Theoretical Background}

Adaptation represents a general property of an organism to adjust to the conditions, in which it exists, including the adjustment of behaviour, perception, thinking and attitudes. A foreign student is an established personality requiring adaptation to the reality and specifics of new society.

How successfully an individual is anchored in the world of their family, school and in the world of people and work is expressed by objective adaptation. Subjective adaptation is evaluated based on how satisfied an individual feels in these areas of life or whether they feel anxious and troubled (Badelina, 2020). The process of adaptation to a new country has usually several phases - leaving the country of origin, legalisation of one's stay; ensuring existential conditions: accommodation, work, language, cultural and social adjustment or return to one's home country. This process is not the same for each individual. Personal variables concerning self-concept (e.g., the perception of one's own potential, selfassessment, own effectiveness, clarity of one's self-concept), and situational variables (influenceability, ability to assess situations as non-accidental or accidental) also play their part. What they have in common is that they have to "adapt to the new environment": to learn new ways of behaving, feeling, and thinking. This can be unexpected and demanding (Furnham, 2019). Adaptation to new environment is perceived as a multi-dimensional variable due to the recognition of more of its dimensions based on various cognitive, emotional and behavioural manifestations (Neely-Prado et al. 2019). Generally speaking, students must adjust in the areas such as new cultural, economic, and social environment of the country given; institutional system of the university given; cultural and social atmosphere of the university given; and new free-time arrangement. It results in various forms of adaptation: Social adaptation is considered a comprehensive lifelong process, in which an individual acquires essential standards, values, habits and behavioural patterns in the culture and society in question, thus becoming its member (Terziev, 2019). It is social support that predicts adaptation to study and university environment (Lee at al., 2018). New culture requires a conscious effort to understand and interpret new verbal, non-verbal, contextual, 
social and other meanings in communication. This is the time of adjustment to a new environment - cultural adaptation. Social cultural adaptation is mainly evaluated based on the living environment adaptation, interpersonal adaptation, and perceived value adaptation. (Luo, Zhang, 2019). Adaptation to study and university is understood as a process leading towards the achievement of such an individual's mental and physical state that enables successful study of the selected field and involvement in social structures at the university of choice and creating positive relations to relevant life and work conditions together with an adequate resistance to stress factors ( $\mathrm{Yu}$, Wright, 2016). Work adaptation represents processes of adjustment to physical work conditions and demands of work activities related to expertise and a new employee's ability to work (Gajda, 2019) in terms of such work contents and character, work conditions, management method and style, work organisation etc. The process can only be successful in case of interaction between personality and environment. Person's ability to satisfy his/her needs without any internal and external conflicts, to perform professional activities, including studying, efficiently is the evidence of high level of adaptation (Latipov et al, 2017).

\section{Methodology}

The authors' objective is to translate the bibliometric analysis of scientific publications into the topic of foreign students' adaptation. There are currently several data platforms suitable for bibliometric analyses. Liao at al. (2017) suggest the databases such as Scopus, Web of Science and Science Direct. Lu (2017) uses Web of Science, Scopus and Google Scholar. We have used Web of Science (hereinafter WoS) for the particular needs of the analysis due to the following: (1) the database provides a wide interdisciplinary extent which corresponds to the character of the topic subject to our research; (2) the WoS service directly integrates a spectrum of suitable tools for bibliometric analyses. Within WoS, we have decided for WoS - Core Collection, as this database is robust and provides a credible overview of today's scientific efforts. It contains over 21,000 reviewed scientific journals of high quality and covers 250 scientific fields, starting from natural and technical sciences and ending with social sciences and humanities (WoS / Core Collection, 2020). An alternative to Core Collection would be Current Content Connect. This, however, is limited to high-profile scientific journals where the quality of research is thoroughly verified (Current Content Connect, 2020). As our goal is to provide a wider overview of current research continuity and publication tendencies, we have decided for Core Collection which to a large extent also includes the WoS / Current Content Connect database.

\subsection{Analysis of Foreign Students Adaptation}

For the purpose of a citation analysis concerning "Foreign students adaptation" the search parameters have been set up through the key words „foreign, students, adaptation“, which has enabled us to search for the articles in headings, key words and abstracts. No limits have been set, not even in relation to the search for document types. This made it possible to create a better overview of publication spectrum: scientific articles, conference papers, book chapters etc. The found documents have subsequently been put in the order based on the number of citations. The following table and chart show the annual number of citations and publications within the topic subject to research. 
Table 1. Citation analysis, the number of quotes and publications to the topic of "foreign students adaptation", database - Web of Science - Core Collection.

\begin{tabular}{|l|l|l|l|l|l|l|l|l|l|l|}
\cline { 2 - 11 } \multicolumn{1}{c|}{} & $\mathbf{2 0 1 1}$ & $\mathbf{2 0 1 2}$ & $\mathbf{2 0 1 3}$ & $\mathbf{2 0 1 4}$ & $\mathbf{2 0 1 5}$ & $\mathbf{2 0 1 6}$ & $\mathbf{2 0 1 7}$ & $\mathbf{2 0 1 8}$ & $\mathbf{2 0 1 9}$ & $\mathbf{2 0 2 0}$ \\
\hline $\begin{array}{l}\text { Number of } \\
\text { publications a year }\end{array}$ & 12 & 23 & 14 & 13 & 35 & 48 & 72 & 70 & 57 & 13 \\
\hline $\begin{array}{l}\text { Number of } \\
\text { citations a year }\end{array}$ & 136 & 124 & 149 & 194 & 189 & 229 & 277 & 302 & 348 & 103 \\
\hline
\end{tabular}

Source: Web of Science, citation analysis, May 2020

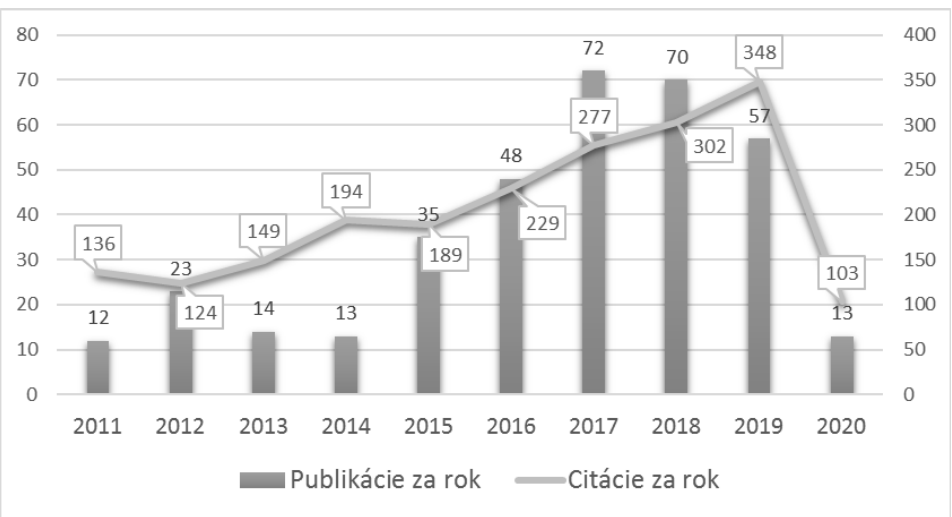

Figure 1. Citation analysis, number of citations and publications concerning the topic of "foreign students' adaptation", database - Web of Science - Core Collection.

Source: Web of Science, quote analysis, May 2020

It is clear from the chart and the table that the number of publications has been growing and that, between the years 2011 and 2019, such a number increased several times and that the number of citations has also been systematically increasing. The total number of publications within this topic is 431 , the h- index is 26 and the average number of citations per item is 6.02 , which can be interpreted as a situation in which the research community is lively and active and is interested in the intellectual and publication activities within the community given. The total number of citating articles and deliverables is $2,142(2,080$ without auto-citations).

The following table (Table 2) has presented the classification of publications based on classification fields - WoS. As expected, the largest number of publications is in the field of education sciences and pedagogical research (47,6\%), social sciences $(10 \%)$, psychology $(7$ $\%$ ), sociology $(6,2 \%)$, and general and special linguistics (together over $10 \%$ ). The rest of the fields does not exceed $3 \%$.

Table 2. Topics of publications as per WoS classification fields.

\begin{tabular}{|l|c|c|}
\hline Research areas as per WoS & Number of records & $\%$ of the total number of 431 \\
\hline Education and pedagogical research & 205 & $47.564 \%$ \\
\hline Social sciences - interdisciplinary approach & 42 & $9.745 \%$ \\
\hline Psychology - interdisciplinary approach & 30 & $6.961 \%$ \\
\hline Sociology & 27 & $6.265 \%$ \\
\hline Linguistic & 25 & $5.800 \%$ \\
\hline Linguistic focused on a particular language & 24 & $5.568 \%$ \\
\hline Social psychology & 21 & $4.872 \%$ \\
\hline
\end{tabular}




\begin{tabular}{|l|c|c|} 
Humanities - interdisciplinary approach & 12 & $2.784 \%$ \\
\hline Applied psychology & 10 & $2.320 \%$ \\
\hline Pedagogical psychology & 9 & $2.088 \%$ \\
\hline Education sciences & 8 & $1.856 \%$ \\
\hline Interdisciplinary sciences & 8 & $1.856 \%$ \\
\hline Communication & 7 & $1.624 \%$ \\
\hline History & 7 & $1.624 \%$ \\
\hline Clinical psychology & 7 & $1.624 \%$ \\
\hline Field/territorial studies & 6 & $1.392 \%$ \\
\hline Business & 6 & $1.392 \%$ \\
\hline Management & 6 & $1.392 \%$ \\
\hline
\end{tabular}

Source: Web of Science, quote analysis, May 2020

The following table (Tab. 3) presents an overview of the most frequently cited articles within the topic given. The search has covered all the databases accessible through WoS in order to find the most relevant articles in the field.

Table 3. Overview of most frequently cited articles within "foreign student's adaptation" topic.
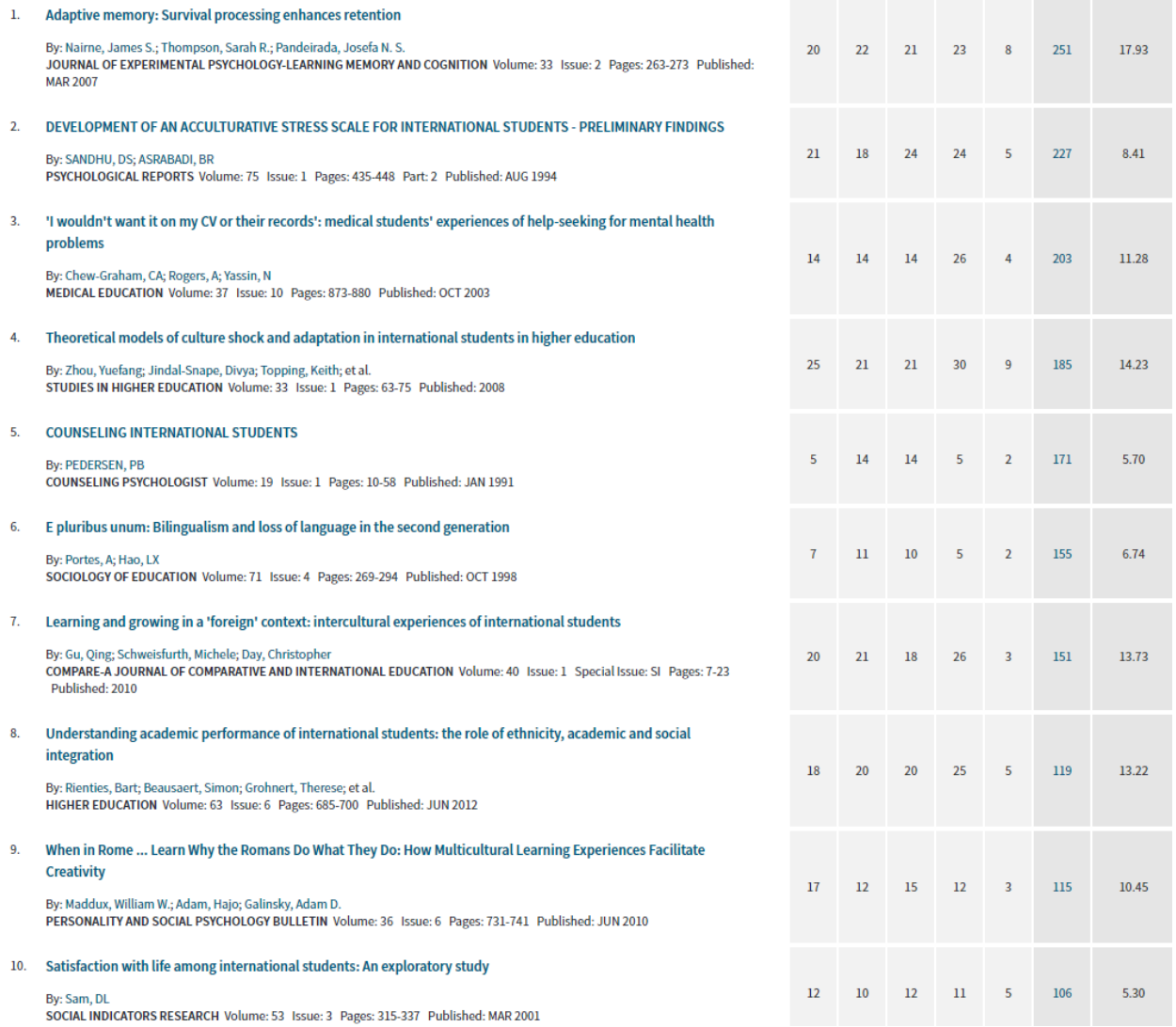

Source: Web of Science, quote analysis, May 2020 


\subsection{Analysis of the topic of foreign students' adaptation during their university study}

Key words: (international student* adaptation (university or study) (problem* or barrier*)) Languages: English All the databases, years without limitation

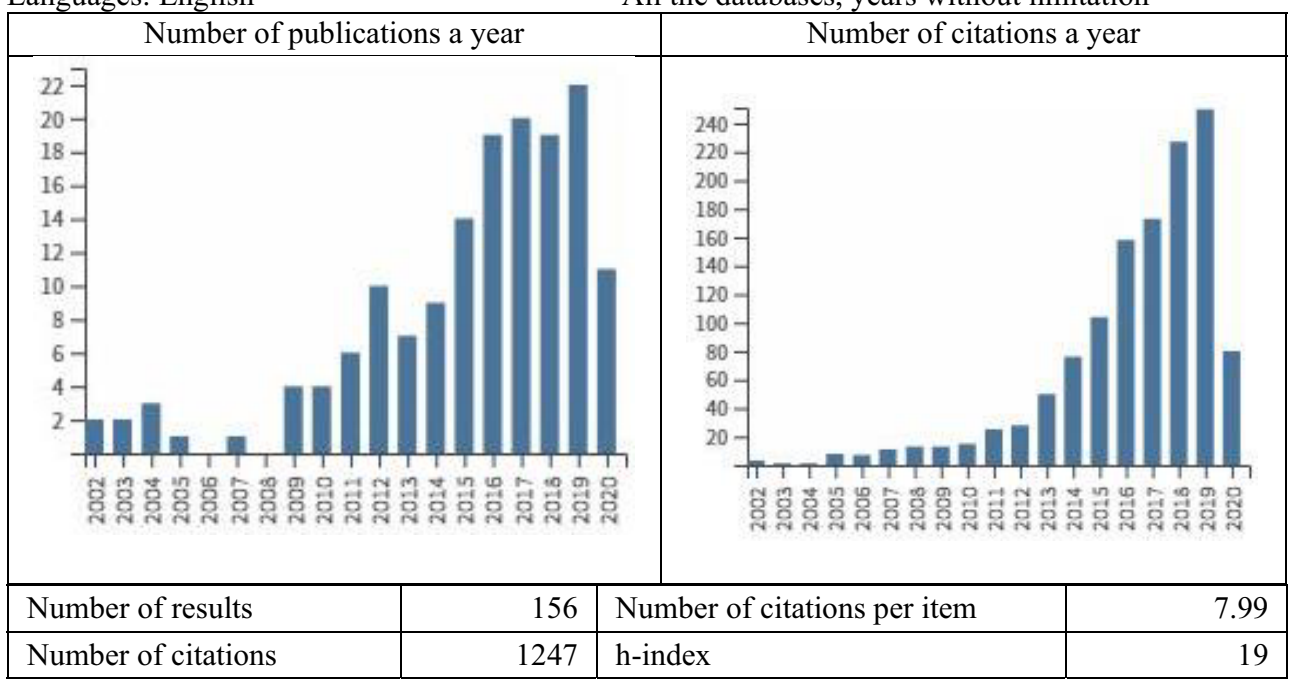

Table 4. Summary of deliverables.

\begin{tabular}{|c|c|c|c|c|}
\hline Name of publication & Authors & Source & Year & Cit. \\
\hline $\begin{array}{l}\text { A review of the acculturation } \\
\text { experiences of international } \\
\text { students }\end{array}$ & $\begin{array}{l}\text { Smith, Rachel A.; } \\
\text { Khawaja, Nigar G. }\end{array}$ & $\begin{array}{l}\text { International } \mathrm{j} \text {. of } \\
\text { intercultural } \\
\text { relations }\end{array}$ & 2011 & 224 \\
\hline $\begin{array}{l}\text { Prevalence of Problematic Mobile } \\
\text { Phone Use in British Adolescents }\end{array}$ & $\begin{array}{l}\text { Lopez-Fernandez, Olatz; } \\
\text { Honrubia-Serrano, L.; } \\
\text { Freixa-Blanxart, } \\
\text { Montserrat; Gibson }\end{array}$ & $\begin{array}{l}\text { Cyberpsychology } \\
\text { behaviour and } \\
\text { social } \\
\text { networking }\end{array}$ & 2014 & 100 \\
\hline $\begin{array}{l}\text { Prevalence of substance use and } \\
\text { delinquent behaviour in } \\
\text { adolescents from Victoria, } \\
\text { Australia and Washington State, } \\
\text { United States }\end{array}$ & $\begin{array}{l}\text { McMorris, B. J.; Hemphill, } \\
\text { S. A.; Toumbourou, J. W.; } \\
\text { Catalano, R. F.; Patton, G. } \\
\text { C. }\end{array}$ & $\begin{array}{l}\text { Health education } \\
\& \text { behaviour }\end{array}$ & 2007 & 94 \\
\hline $\begin{array}{l}\text { Crossing the distance: Adjustment } \\
\text { of Taiwanese graduate students in } \\
\text { the United States }\end{array}$ & Swagler, MA; Ellis, MV & $\begin{array}{l}\text { J. of counselling } \\
\text { psychology }\end{array}$ & 2003 & 75 \\
\hline $\begin{array}{l}\text { Why can't we be friends?: } \\
\text { Multicultural attitudes and } \\
\text { friendships with international } \\
\text { students }\end{array}$ & $\begin{array}{l}\text { Williams, Christina T.; } \\
\text { Johnson, L. R. }\end{array}$ & $\begin{array}{l}\text { International j. of } \\
\text { intercultural } \\
\text { relations }\end{array}$ & 2011 & 68 \\
\hline $\begin{array}{l}\text { Profiles of Acculturative } \\
\text { Adjustment Patterns Among } \\
\text { Chinese International Students }\end{array}$ & $\begin{array}{l}\text { Wang, Kenneth T.; } \\
\text { Heppner, P. P.; Fu, Chu- } \\
\text { Chun; Zhao, R.; Li, F.; } \\
\text { Chuang }\end{array}$ & $\begin{array}{l}\text { J. of counselling } \\
\text { psychology }\end{array}$ & 2012 & 63 \\
\hline $\begin{array}{l}\text { Critical issues of literature on } \\
\text { counselling international students }\end{array}$ & Yoon, E; Portman, T.A.A & $\begin{array}{l}\text { J. of } \\
\text { multicultural } \\
\text { counselling and } \\
\text { development }\end{array}$ & 2004 & 55 \\
\hline $\begin{array}{l}\text { Homesickness and Adjustment in } \\
\text { University Students }\end{array}$ & $\begin{array}{l}\text { Thurber, C. A.; Walton, } \\
\text { E.A. }\end{array}$ & $\begin{array}{l}\text { J. of American } \\
\text { college health }\end{array}$ & 2012 & 54 \\
\hline
\end{tabular}




\begin{tabular}{|c|c|c|c|c|}
\hline $\begin{array}{l}\text { Internationalisation of higher } \\
\text { education: integrating } \\
\text { international students into } \\
\text { Canadian academic environment }\end{array}$ & $\begin{array}{l}\text { Guo, Shibao; Chase, } \\
\text { Mackie }\end{array}$ & $\begin{array}{l}\text { Teaching in } \\
\text { higher education }\end{array}$ & 2011 & 45 \\
\hline $\begin{array}{l}\text { Promoting Intercultural Contact } \\
\text { on Campus: A Project to Connect } \\
\text { and Engage International and Host } \\
\text { Students }\end{array}$ & Campbell, Nittaya & $\begin{array}{l}\text { J. of studies in } \\
\text { international } \\
\text { education }\end{array}$ & 2012 & 40 \\
\hline $\begin{array}{l}\text { Assessing the predictive validity } \\
\text { of cultural intelligence over time }\end{array}$ & $\begin{array}{l}\text { Ward, C.; Wilson, J.; } \\
\text { Fischer, R. }\end{array}$ & $\begin{array}{l}\text { Personality and } \\
\text { individual } \\
\text { differences }\end{array}$ & 2011 & 35 \\
\hline $\begin{array}{l}\text { Italian Adolescent Gambling } \\
\text { Behaviour: Psychometric } \\
\text { Evaluation of the South Oaks } \\
\text { Gambling Screen: Revised for } \\
\text { Adolescents (SOGS-RA) Among } \\
\text { a Sample of Italian Students }\end{array}$ & $\begin{array}{l}\text { Colasante, E.; Gori, M.; } \\
\text { Bastiani, L.; Scalese, M.; } \\
\text { Siciliano, V.; Molinaro S. }\end{array}$ & $\begin{array}{l}\text { J. of gambling } \\
\text { studies }\end{array}$ & 2014 & 32 \\
\hline $\begin{array}{l}\text { The Birth of Academic } \\
\text { Subalterns: How Do Foreign } \\
\text { Students Embody the Global } \\
\text { Hegemony of American } \\
\text { Universities? }\end{array}$ & Kim, Jongyoung & $\begin{array}{l}\text { J. of studies in } \\
\text { international } \\
\text { education }\end{array}$ & 2012 & 26 \\
\hline $\begin{array}{l}\text { Exploring the experiences and } \\
\text { coping strategies of international } \\
\text { medical students }\end{array}$ & Malau-Aduli, Bunmi S. & $\begin{array}{l}\text { Bmc medical } \\
\text { education }\end{array}$ & 2011 & 23 \\
\hline $\begin{array}{l}\text { Understanding the symbolic } \\
\text { capital of intercultural } \\
\text { interactions: a case study of } \\
\text { international students in Australia }\end{array}$ & Lien Pham; Ly Tran & $\begin{array}{l}\text { International } \\
\text { studies in } \\
\text { sociology of } \\
\text { education }\end{array}$ & 2015 & 22 \\
\hline $\begin{array}{l}\text { Internationalization of Canadian } \\
\text { higher education: discrepancies } \\
\text { between policies and international } \\
\text { student experiences }\end{array}$ & Guo, Yan; Guo, Shibao & $\begin{array}{l}\text { Studies in higher } \\
\text { education }\end{array}$ & 2017 & 21 \\
\hline
\end{tabular}

Source: authors, 2021

\subsection{Analysis of foreign students' adaptation to labour market}

Key words: (international student* (job* or labour or labour/ market adaptation) Languages: English All the databases, years without limitations

\begin{tabular}{|l|l|l|}
\hline \multicolumn{2}{|c|}{ Number of publications a year } & \multicolumn{2}{|c|}{ Number of citations a year } \\
\hline${ }^{4} 7$ & & 10 \\
\end{tabular}


Table 5. Summary of deliverables.

\begin{tabular}{|c|c|c|c|c|}
\hline Name of publication & Authors & Source & Year & Cit. \\
\hline $\begin{array}{l}\text { Making Careers in the } \\
\text { Occupational Niche: Chinese } \\
\text { Students in Corporate Japan's } \\
\text { Transnational Business }\end{array}$ & Liu-Farrer, Gracia & $\begin{array}{l}\text { J. of Ethnic and Migration } \\
\text { Studies }\end{array}$ & 2011 & 26 \\
\hline $\begin{array}{l}\text { Hitting, Missing, And in } \\
\text { Between: A Typology of the } \\
\text { Impact of Western Education } \\
\text { on the Non-Western World }\end{array}$ & $\begin{array}{l}\text { Grigorenko, Elena } \\
\text { L. }\end{array}$ & Comparative Education & 2007 & 13 \\
\hline $\begin{array}{l}\text { Appropriation of Foreign } \\
\text { Approaches for Sustainable } \\
\text { Development and } \\
\text { Transformational Changes in } \\
\text { Vietnamese Vocational } \\
\text { Education }\end{array}$ & $\begin{array}{l}\text { Tien Thi Hanh Ho; } \\
\text { Ly Thi Tran }\end{array}$ & $\begin{array}{l}\text { Higher Education Skills } \\
\text { And Work-Based } \\
\text { Learning }\end{array}$ & 2018 & 1 \\
\hline $\begin{array}{l}\text { More Active Outside the } \\
\text { Classroom Chinese } \\
\text { International Students' } \\
\text { Interactions with Chinese } \\
\text { Communities in Australia }\end{array}$ & Gao, Jia & J. of Chinese Overseas & 2016 & 1 \\
\hline $\begin{array}{l}\text { Gender Segregation in } \\
\text { Occupational Expectations } \\
\text { and in the Labour Market: } \\
\text { International Variation And } \\
\text { the Role of Education And } \\
\text { Training Systems }\end{array}$ & Hillmert, Steffen & $\begin{array}{l}\text { Gender Segregation in } \\
\text { Vocational Education }\end{array}$ & 2015 & 1 \\
\hline $\begin{array}{l}\text { Development of Intercultural } \\
\text { Competence of Students with } \\
\text { Disabilities in the Process of } \\
\text { Improving a Foreign } \\
\text { Language }\end{array}$ & $\begin{array}{l}\text { Kireeva, Irina } \\
\text { Anatolyevna a kol. }\end{array}$ & $\begin{array}{l}\text { Modern J. of Language } \\
\text { Teaching Methods }\end{array}$ & 2018 & 0 \\
\hline $\begin{array}{l}\text { Developing Students' } \\
\text { Leadership Skills at Higher } \\
\text { Educational Institutions for } \\
\text { Their Successful Adaptation } \\
\text { at the Labour Market }\end{array}$ & $\begin{array}{l}\text { Mizintseva, M.; } \\
\text { Sardarian, A.; } \\
\text { Petrochenko, A. }\end{array}$ & $\begin{array}{l}\text { Proceedings of the } 2 \mathrm{nd} \\
\text { International Conference } \\
\text { on Social, Economic and } \\
\text { Academic Leadership } \\
\text { (Icseal 2018) }\end{array}$ & 2018 & 0 \\
\hline $\begin{array}{l}\text { Global Pressure or National } \\
\text { Identity: Strategic Challenges } \\
\text { for Russian Business Schools }\end{array}$ & $\begin{array}{l}\text { Gerasimenko, V.; } \\
\text { Molchanova, O. }\end{array}$ & Serbian J. of Management & 2017 & 0 \\
\hline $\begin{array}{l}\text { Study Regarding Dimensions } \\
\text { of Graduates Satisfaction of } \\
\text { the Military Higher } \\
\text { Education Institutions }\end{array}$ & $\begin{array}{l}\text { Stoenica, } \\
\text { Laurentiu } \\
\text { Florentin }\end{array}$ & $\begin{array}{l}\text { Inted2017: } 11 \text { th } \\
\text { International Technology, } \\
\text { Education and } \\
\text { Development Conference }\end{array}$ & 2017 & 0 \\
\hline $\begin{array}{l}\text { Graduate Students } \\
\text { Satisfaction of Business } \\
\text { Administration Bachelor's } \\
\text { Program }\end{array}$ & $\begin{array}{l}\text { Vasiliu, Cristinel; } \\
\text { Albastroiu, I.; } \\
\text { Dina, Razvan }\end{array}$ & $\begin{array}{l}\text { Basiq International } \\
\text { Conference: New Trends } \\
\text { in Sustainable Business } \\
\text { and Consumption } 2017\end{array}$ & 2017 & 0 \\
\hline $\begin{array}{l}\text { Approaches to Designing a } \\
\text { Language Course for } \\
\text { Engineering Students }\end{array}$ & $\begin{array}{l}\text { Sidorenko, T.; } \\
\text { Loginova, A. }\end{array}$ & $\begin{array}{l}\text { Inted2015: 9th } \\
\text { International Technology, } \\
\text { Education and } \\
\text { Development Conference }\end{array}$ & 2015 & 0 \\
\hline
\end{tabular}




\begin{tabular}{|c|c|c|c|c|}
\hline $\begin{array}{l}\text { Navigating the Impending } \\
\text { Mooc Storm in Middle } \\
\text { Eastern Higher Education }\end{array}$ & Gallacher, D. & $\begin{array}{l}\text { Inted2014: 8th } \\
\text { International Technology, } \\
\text { Education and } \\
\text { Development Conference }\end{array}$ & 2014 & 0 \\
\hline $\begin{array}{l}\text { Analysis of Reform on } \\
\text { Badminton Specialist Course }\end{array}$ & $\begin{array}{l}\text { Wang, Jin Liang; } \\
\text { Chen, Xiao Xia }\end{array}$ & $\begin{array}{l}2012 \text { 2nd International } \\
\text { Conference on Physical } \\
\text { Education and Society } \\
\text { Management (Icpesm } \\
\text { 2012), Vol. } 9\end{array}$ & 2012 & 0 \\
\hline $\begin{array}{l}\text { Elearning in Lithuania: } \\
\text { Overcoming Barriers } \\
\text { Towards Universal Access to } \\
\text { Education }\end{array}$ & $\begin{array}{l}\text { Rutkauskiene, } \\
\text { Danguole; } \\
\text { Pociute, Egle }\end{array}$ & $\begin{array}{l}\text { 3rd Internat. Conference } \\
\text { on Politics and } \\
\text { Information Systems: } \\
\text { Technologies and } \\
\text { Applications, Proceedings }\end{array}$ & 2005 & 0 \\
\hline $\begin{array}{l}\text { Executive Economic } \\
\text { Thinking Changes in } \\
\text { Lithuania in Global Economy } \\
\text { Context }\end{array}$ & $\begin{array}{l}\text { Ciburiene, J; } \\
\text { Pukeliene, V }\end{array}$ & $\begin{array}{l}\text { EISTA '04: International } \\
\text { Conference on Education } \\
\text { and Information Systems: } \\
\text { Technologies and } \\
\text { Applications, Vol. } 3\end{array}$ & 2004 & 0 \\
\hline
\end{tabular}

Source: authors, 2021

The results show that the process of foreign student's adaptation runs on several levels and includes the psychological, social, cultural, climatic, physiologic, and inter-cultural adaptation, closely relating to the mental, emotional, intellectual and physical load. We support the opinion that it is necessary to increase the interest in and pay more attention to the given issue. This has to be achieved not only by the pedagogical employees of the Department of Social Sciences but also by the tutors of the first years, freshmen students and faculty management. As part of our conclusion, it is to be stated that we have reached our goal concerning the submitted research. The results can be of benefit for more specific and professional preparation of the issue given. At the same time, they contain the proposal of alternative solutions and recommendations related to the improvement of the current adaptation process state at universities.

\section{Discussion and Conclusion}

The bibliometric analysis has discovered that most of the existing research focuses on the small children's or secondary school students' adaptation. to schools. Not many of them, however, focus on university students though. Foreign students represent a significant part of the Slovak higher education sector. For many students from nearby Slavic countries the completion of Slovak university study means more opportunities in the labour market. In order to successfully adapt to, integrate in and settle into a new environment, this group of foreigners clearly needs support and help of various players, with whom they come into contact in various areas of integration - education, accommodation, employment, health and social care, cultural and social integration etc. Thus, the adoption of several internal, national reforms focused on higher education study and active employment policy needs to be emphasised. Help with the adaptation to a different study and social environment increases positive study, work and stay results. Foreign students thus often become more self-confident and open to both coexistence and various ideas related to work life, and have better social and language skills. Many of these benefits occur naturally as the consequence of adjustment to the demands of life in a foreign environment, meeting different types of people and relying on one's abilities. Help and special consultancy aimed at students' preparation for a multicultural environment and easier adaptation to different study and social environments have increased the positive results of one's study, work and stay. 


\section{Acknowledgements}

Education of foreign students with the emphasis on creating key competences in the context of building work carrier and inclusion in the Slovak labour market (No. 049TUKE-4/2019).

\section{References}

1. Badelina, M. V. (2020). Process of adaptation of first-year students to study at university as pedagogical phenomenon: structure and characteristics. Amazonia Investiga, 9(27), 460-477.

2. Current Contents Connect (2020). Clarivate. https://clarivate.com/

3. Ferencz, V., Hrehová, D., \& Seňová, A. (2020). Higher education require adaptation of students study abroad programs. SHS Web of Conferences 74(3-4), Article 02003.

4. Furnham, A. (2019). Culture Shock: A Review of the Literature for Practitioners. Psychology, 10(13), 1832-1855.

5. Gajda, J. (2019). Professional Adaptation of New Employees to the Organization. CzOTO, 1(1), 929-938.

6. Johnson, K. (2020). International Higher Education Hotspots: International Student Mobility Growth in Nontraditional Destination Countries. Journal of International Students, 10(1).

7. Latipov, Z. A., Ziyatdinov, A. M., Demidova, L. A., Gerasimov, V., \& Zaostrovtseva, M. N. (2017). The problem of adaptation of foreign students studying in Russian universities. Especial, 38(56), 1-27.

8. Lee, Ch., Sung, Y. T., Zhou, Y. \& Lee, S. (2018). The relationships between the seriousness of leisure activities, social support and school adaptation among Asian international students in the U.S. Leisure Studies, 37(2), 197-210.

9. Liao, Y., Deschamps, F., Loures, E. D. F. R., \& Ramos, L. F. P. (2017). Past, present and future of Industry 4.0-a systematic literature review and research agenda proposal. International journal of production research, 55(12), 3609-3629.

10. Lu, Y. (2017). Industry 4.0: A survey on technologies, applications and open research issues. Journal of Industrial Information Integration, 6, 1-10.

11. Luo, M., \& Zhang, X. (2019). Research Status about Influence Factors of International Students' Cross-Cultural Adaptation with Different Models. Open Journal of Social Sciences, 9(6), Article 5163.

12. Neely-Prado, A., Navarrete, G., \& Huepe, D. (2019). Socio-affective and cognitive predictors of social adaptation in vulnerable contexts. PLoS ONE, 14(6), Article e0218236.

13. Smith, R. A., \& Khawaja, N. G. (2011). A review of the acculturation experiences of international students. International Journal of Intercultural Relations, 35(6), 699-713.

14. Terziev, V. (2019). Conceptual framework of social adaptation. Ijasos, 5(13), 6-15.

15. Yu, B.H., \& Wright, E. (2016). Socio-Cultural Adaptation, Academic Adaptation and Satisfaction of International Higher Degree Research Students in Australia. Tertiary Education and Management, 22, 49-64. 